\title{
Japan moves to evaluate its engineers
}

[TOKYO] Japan is to set up a body to evaluate engineering and technology departments at universities in an effort to raise teaching standards to Western levels.

The move is a response to industry's concern about the poor quality of Japanese engineers (see Nature 393, 724; 1998). Because Japanese universities lack an adequate system of evaluation, companies say that they have been unable to determine the standard of engineering graduates.

The new body, Japan Accreditation Board for Engineering Education (JABEE), will be launched tomorrow (30 April) by the Japanese Society for Engineering Education (JSEE), which represents both industry and the academic community.

Modelled on accreditation bodies in the West, such as the US Accreditation Board for Engineering and Technology, JABEE will certify engineering, technology and applied science programmes according to the quality of teaching and curricula that are provided by the universities.

In addition to basic training in engineering and technology, JABEE will require such programmes to include teaching in humanities, such as ethics and communication studies, as well as English-language training. The accreditation process will officially start in
2001 after one to two years of experimental operation, with mutual accreditation by US and British accreditation bodies.

Some are concerned that such a system may not be accepted by universities, which have in the past been generally reluctant to endorse external evaluation (see Nature 397, 378; 1999). But Koji Harada, an executive director of JSEE, says: "This is no time to argue whether to introduce the evaluation system or not. Engineering is a global business, and Japan is the only developed country which does not have an internationally recognized standard for engineering education.”

Despite a recent proposal by the Asia Pacific Economic Cooperation (APEC) forum to introduce a professional recognition system for engineers, called APEC Engineers Register, Australia and New Zealand are the only member countries which have internationally recognized accreditation bodies for engineering education.

Under the current proposal, 'APEC engineers' would have to graduate from universities approved by recognized accreditation bodies, and have at least seven years' professional experience in engineering.

"The problem with most Japanese universities is that technical training is not emphasized enough in their engineering pro-

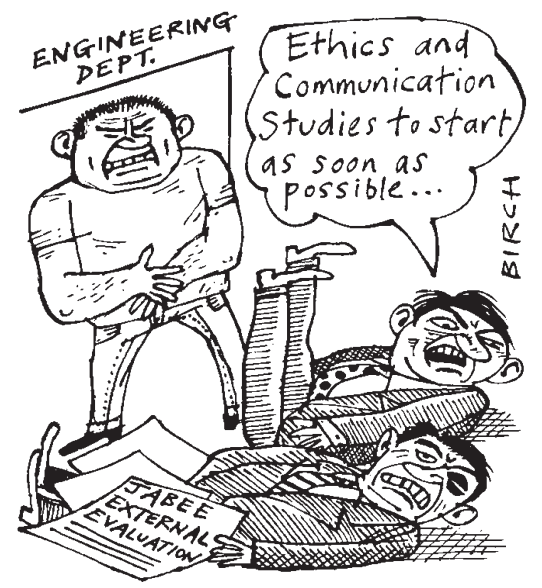

grammes," says Harada. "Since engineering is regarded as an academic subject, most engineering graduates are not equipped with technical skills required by industry. Strictly speaking, engineers in Japan cannot be regarded as such in international terms."

Many blame this situation on the collapse of Japan's lifetime-employment system, which invests heavily in training new graduates. With the recent economic crisis, increasing numbers of companies are cutting back on training to save money, and are abandoning lifetime employment for contractbased employment.

AsakoSaegusa

\section{University libraries put pen to paper in journal pricing protest}

[MUNICH] Leading specialist science-journal publishers have responded cautiously to an open letter signed by German, Austrian, Swiss and Dutch university libraries asking how they propose to keep prices affordable in future.

The letter was sent out in January, and pointed out that the announced increase in the price of journal subscriptions in 1999 was significantly above that of library budgets. The highest increases were from MCB University Press (27.3 per cent), Wiley (20 per cent) and Elsevier Science (19 per cent).

Most of the publishers replied by saying that their pricing policies for 2000 and beyond are not yet fixed. Some, such as Wiley, indicated that they were prepared to discuss the issue with libraries in the next months a move welcomed by librarians, who say that publishers usually refuse to discuss pricing policy with them.

Elsevier promised to keep price rises next year below 10 per cent, but this statement has not reassured librarians, who still find the increase too high. Göttingen University librarian Elmar Mittler, for example, points out that although library budgets, which are paid out of public funding, are not necessarily falling, any increase is usually only a few per cent. "Last year we fought for, and won, a sup-

\begin{tabular}{|c|c|c|c|c|}
\hline \multicolumn{5}{|c|}{ Price increases and impact factors for some specialist science journals } \\
\hline Title & Publisher & $\begin{array}{l}\text { Sub. } P \\
1998\end{array}$ & $\begin{array}{l}\text { (DM) } \\
1999\end{array}$ & Impact factor \\
\hline Cell & Cambridge Cell Press & 1,220 & 1,329 & 37.3 \\
\hline Neuron & Cambridge Cell Press & 1,120 & 1,120 & 15.8 \\
\hline EMBO Journal & IRL/Oxford Univ. Press & 2,144 & 2,325 & 12.6 \\
\hline PNAS & Academy of Sciences & 1,437 & 1,904 & $9.0^{-1}$ \\
\hline Angewandte & Chemie Wiley/VCH & 2,398 & 2,898 & 8.6 \\
\hline $\begin{array}{l}\text { Journal of Biological } \\
\text { Chemistry }\end{array}$ & $\begin{array}{l}\text { Soc. of Biochemistry } \\
\text { and Mol. Biol. }\end{array}$ & 3,200 & 3,200 & 7.0 \\
\hline Biochemistry & Am Chem. Soc. & 4,358 & 5,100 & 4.6 \\
\hline Glia & Wiley/Liss & 3,600 & 3,870 & 3.8 \\
\hline FEBS Letters & Elsevier & 6,065 & 6,879 & 3.5 \\
\hline Brain Research & Elsevier & 24,404 & 27,228 & 2.1 \\
\hline Gene & Elsevier & 12,137 & 12,817 & 1.8 \\
\hline
\end{tabular}

Table taken from Laborjournal, Freiburg

plementary fund of DM1.2 million (US\$651,200) to keep up subscriptions at Göttingen University library. But even so, we still had to cancel 150 subscriptions," he says.

Derk Haank, chairman of Elsevier Science, told Nature that Elsevier has been forced to introduce high price rises because of changes in exchange rates. Also, he says, the rising number of submissions to some journals means that they have to increase in size.

The librarians' letter points out that market forces do not operate in the world of research publications - researchers need access to many journals, and most are con- trolled by a small number of large publishing houses. Electronic access to these journals does not as yet offer a solution to high prices, as publishing houses tend to offer all-inclusive deals for paper and electronic forms.

Reinhardt says scientists need to change their attitudes towards publishing and boycott over-expensive journals. But an article in this month's Laborjournal, a German magazine for biological scientists, says researchers select their journals more on impact factor than price. The article points out, separately, that impact factor often correlates inversely with price (see table).
Alison Abbott 